\title{
Civil governance in work and employment relations: how civil society organizations contribute to systems of labour governance
}

\author{
Williams, S., Abbott, B. and Heery, E. (forthcoming) 'Civil governance in work and \\ employment relations: how civil society organizations contribute to systems of labour \\ governance', paper accepted by the Journal of Business Ethics on the 5th August 2015 \\ DOI: $10.1007 / \mathrm{s} 10551-015-2812-0$
}

\begin{abstract}
$\underline{\text { Abstract }}$
Civil society organizations (CSOs) attempt to induce corporations to behave in more socially responsible ways, with a view to raising labour standards. A broader way of conceptualizing their efforts to influence the policies and practices of employers is desirable, one centred upon the concept of civil governance. This recognizes that CSOs not only attempt to shape the behaviour of employers through the forging of direct, collaborative relationships, but also try to do so indirectly, with interactions of various kinds with the state being integral.

Drawing on evidence derived from UK-based CSOs involved in work and employment relations, four types of civil governance are identified and characterized. By elaborating the concept of civil governance, and demonstrating how different types of civil governance operate, the research extends our knowledge and understanding of how CSOs, as increasingly prominent actors in the field of work and employment relations, operate within, and contribute to, systems of labour governance.
\end{abstract}

\section{$\underline{\text { Keywords }}$}

Civil governance; regulation; governance; civil society organizations; political corporate social responsibility; labour standards 
$\underline{\text { Abbreviations used }}$

CSO - Civil Society Organization

CSR - Corporate Social Responsibility

UKBA - United Kingdom Border Agency 


\section{Civil governance in work and employment relations: how civil society organizations contribute to systems of labour governance}

\section{Introduction}

There is growing interest in the relationship between civil society organizations (CSOs) and business (e.g. Burchell and Cook, 2013; Yaziji and Doh, 2009), particularly with regard to how far their interventions induce corporations to behave in more socially responsible ways (e.g. Fransen, 2012; Fransen and Burgoon, 2013). Much of this concern relates to the efforts of CSOs to regulate the behaviour of firms, through governance arrangements that enable them to exercise oversight over, and influence, business policy and practice (Newell, 2008). However, much of the extant work on the topic of civil regulation is rather narrowly conceived, being situated within the ambit of private regulation, and thus restricted to the production of non-statutory norms, codes and standards of good business practice through collaborative relationships between CSOs and firms. We use this article to advance a broader approach to understanding how CSOs influence the policies and practices of employers, centred upon the concept of civil governance. This captures the way in which CSO interventions form part of the 'regulatory state' (Levi-Faur, 2009), and is consistent with the increasingly prominent 'political' perspective on corporate social responsibility (CSR) which views it as a mode of governance (e.g. Baur and Schmitz, 2012; Scherer and Palazzo, 2011).

Drawing on data collected during two periods - in 2008 and 2012 - from UK-based CSOs, the principal original aim of the research was to investigate the role and activities of such organisations as actors in work and employment relations, particularly as agents of worker representation. The research was concerned with elucidating the methods they use to achieve 
their objectives in this area, within a discrete national-setting, and with examining the nature of their relationships with other relevant actors, particularly employers, trade unions and government. As the research progressed, however, a greater emphasis came to be placed on trying to make sense of how CSOs operate as regulatory institutions, helping to shape employment policy and practice both with regard to their own discrete interventions and through their interactions with other actors. There were two reasons for focusing on CSOs involved in the field of work and employment relations. The first concerns the marked growth of interest in the nature of the complex, multi-dimensional regulatory environment, particularly at transnational level, where new forms of private regulation, such as codes of labour conduct, have become prominent features of the governance landscape (e.g. Bartley, 2007; Locke, 2013; Wells, 2007). Second, the decline of trade unions, the traditional representative agents of working people, mean that the activities of new and emerging actors in employment relations, including CSOs, have attracted more attention (e.g. Heery and Frege, 2006; Tapia et al, 2015; Williams et al, 2011a).

The review of relevant literature, which covers topics including regulatory change and civil regulation, is used to highlight the conceptual value of the civil governance approach, set against the rising interest in both the question of 'governance' and the related concept of 'political' corporate social responsibility. The concept of civil governance enables the broader ways in which CSOs seek to influence employers' policy and practice, not just directly, through collaborations with firms, but also indirectly, as part of the wider regulatory state, to be captured appropriately. The research findings are then used to identify and characterize four types of civil governance - the 'business-focused', 'rights-based', 'advocacy-based' and 'service-oriented' approaches respectively - each of which is marked by a specific mode of interaction between CSOs, employers, working people, trade unions 
and government. The research findings also highlight the extent to which national-level changes in economic and political contexts can influence the efficacy of particular types of civil governance. By elaborating the concept of civil governance, and demonstrating how different types of civil governance operate, the research makes an important contribution to extending our knowledge and understanding of how CSOs, as increasingly prominent actors in the area of work and employment relations, operate within, and contribute to, systems of labour governance. While the specific civil governance configuration evident in the UK field of work and employment relations is likely to be highly context specific, the concept of civil governance regimes offers a useful way forward for researchers in other fields wanting to explore how CSOs influence business policy and practice within discrete national settings.

\section{From civil regulation to civil governance}

In recent years there has been a growing emphasis on understanding the more complex regulatory environment within which business organizations operate, and also with what regulation means, with reference to concepts such as the 'regulatory state', 'regulatory capitalism' and 'governance' (e.g. Ayers and Braithwaite, 1992; Braithwaite 2008; Grabosky, 1995; Grabosky, 2013; Levi-Faur, 2009; Levi-Faur, 2012). There has also been an increasing concern about the need to make use of the tools and concepts derived from the literature on regulation in the field of business ethics, as the foundation of a 'regulatory approach' to business ethics (Norman, 2011). Moreover, a concern with governance issues is central to the concept of 'political' corporate social responsibility (CSR) (e.g. Baur and Arenas, 2014; Knudsen and Moon, 2013; Moon and Vogel, 2008; Scherer and Palazzo, 2007; Scherer and Palazzo, 2011). Conventionally CSR was viewed as a private, instrumental matter, with an emphasis given to how it serves the business self-interest of firms. Lately, however, stimulated by studies which examine the institutional diversity of CSR in comparative 
perspective (e.g. Matten and Moon, 2008), there has been a move to characterize it as a public, and thus political, phenomenon (e.g. Baur and Schmitz, 2012; Gond et al, 2011).

Moreover, the rise of private regulatory arrangements demonstrates how arrangements for regulating business activity are evolving, especially at transnational level, with important implications for understanding CSR. Corporations themselves, sometimes in association with other non-state actors like CSOs, increasingly determine the regulatory framework within which they operate (Chan and Pattberg, 2008; Grabosky, 2013; Vogel, 2008). Private regulation, manifest in formal codes of conduct, monitoring arrangements and certification schemes, has become an increasingly important feature of the global regulatory landscape, most notably in the areas of labour and environmental standards (e.g. Bartley, 2003; Bartley, 2007; Bartley, 2011; Donaghey et al, 2014; Egels-Zandén, 2007; Esbenshade, 2012; Gulbrandsen, 2010; Locke, 2013; Pattberg, 2005; Vogel, 2010). This development is related to the emergence of global supply chains and pressure on multinationals to exhibit greater CSR (Fransen, 2013; Fransen and Burgoon, 2012; Knudsen, 2013; Wells, 2007). The rise of 'transnational private governance' (Pattberg, 2005) or 'transnational private regulation' (Bartley, 2007), is linked to the diminished regulatory capacities of nation-states and the absence of effective multilateral governance arrangements in a more globalized world; a response to the regulatory 'gap' or 'vacuum' evident at a global level (Esbenshade, 2004; Wells, 2007). Increasingly this is being filled by private, voluntary and non-state arrangements for regulating economic activity, such as certification schemes and other forms of 'soft' (non-binding) rather than 'hard' (legally binding) law (Wells, 2007). Private regulation relies upon 'market' sanctions for its effectiveness, such as the threat of consumer boycotts (O'Rourke, 2003; O’Rourke, 2005), rather than legal penalties. 
Sensing opportunities to expand their influence over the behaviour of corporations (Moon and Vogel, 2008; Vogel, 2010), particularly with regard to improving social and environmental standards (Gunningham 2009), CSOs are often involved in designing, operating and monitoring systems of private regulation (e.g. Chan and Pattberg, 2008; Todd Beer et al, 2012). Partnerships between CSOs and firms are a commonplace feature of private regulatory arrangements (Bartley, 2003; Bartley, 2007; Utting, 2005). Indeed, much of the impetus for private regulation seems to have emanated from CSOs (Baur and Arenas, 2014). In this way, then, civil society actors, particularly activist groups and social movements, play an important part in inducing firms to operate in a more socially responsible manner (den Hond and de Bakker, 2007), not least by rendering private regulatory arrangements more effective (Fransen, 2012; Fransen and Burgoon, 2012).

The role of CSOs in this area points to the efforts which have been made to distinguish between different manifestations of private regulation. Clearly, business self-regulation, on a firm, industry or supply-chain basis, is one notable type. When it comes to regulatory initiatives that involve corporations and CSOs, such as the US-based Fair Labor Association, the term 'multi-stakeholder regulation' is preferred by some (e.g. Everett et al, 2008; Utting, 2012). Other labels which recognize the existence of regulatory partnerships between business and CSOs include 'joint civil-business regulation' (Reed, 2012) and 'civil coregulation' (Steurer, 2013). Given the growing attention being devoted to the regulatory activities of CSOs (e.g. Todd Beer et al, 2012), scholars have begun to reflect on the nature and implications of an emerging regime of 'civil regulation', as applied to governance arrangements that enable civil society actors to exercise oversight over, and influence, business activity (e.g. Bendell, 2000; Chan and Pattberg, 2008; Gunningham, 2009; Moon and Vogel, 2008; Newell 2008; Vogel, 2005; Vogel, 2010; Zadek, 2007). 
This development raises the important question of what kind of leverage do CSOs use in their efforts to influence the behaviour of firms? In much of the literature there is an emphasis on the potency of confrontational approaches, encompassing protests, boycotts and other forms of social activism designed to challenge business interests (e.g. Bartley and Child, 2014; den Hond and den Bakker, 2007; Kneip, 2013; Seidman, 2007; Utting, 2005). Even if collaborations between CSOs and firms have perhaps become more prominent, the relationship between them can often be antagonistic. Some view this relationship in terms of a complex and dynamic mix of conflict and collaboration (e.g. Arenas et al, 2013; Yaziji and Doh, 2009). Moreover, Burchell and Cook (2013: 752) explore how businesses and CSOs relate to each other as actors and, as well as contesting the 'meaning and language of CSR', create the possibility for a 'range of differing strategies for engagement'. For Utting (2012: 39), however, the distinction between 'confrontation' and 'collaboration' is less useful than an approach which distinguishes between efforts by CSOs to promote 'voluntary' social responsibility by corporations and attempts to make them more accountable through robust enforcement arrangements.

Growing interest in civil regulation, though, has largely been predicated on the belief that CSOs can best achieve their objectives by collaborating with business organizations. The concept of civil regulation was initially elaborated by Bendell (2000: 246), who observed that CSOs: 'are setting the standards for corporate behaviour, through dialogue with management, and corporations are increasingly choosing to adopt these standards'. The conceptualization of civil regulation articulated in much of the extant literature, where it is used to refer to the non-statutory norms, codes and standards of good practice generated by CSOs designed to influence the behaviour of businesses (Vogel, 2010), is rather narrow. There is an assumption 
that inducing firms to operate in a more socially responsible fashion, and thus raise standards, is best achieved through collaborative methods, linked to the deployment of business case arguments for change (e.g. Bendell, 2000; Hutter and O’Mahony, 2004; Zadek, 2007). CSO interventions can support, and give legitimacy to, business efforts to improve their social and environmental performance, and thus should be welcomed by firms, rather than seen as challenging their authority (Hutter, 2006).

There are three prominent themes within the emerging literature on both the relationship between CSOs and business and the nature of civil regulation. One concerns the questionable efficacy of the business case for regulatory intervention. Civil society actors often make use of business case arguments when attempting to influence corporate practice, designed to help employers manage people at work in an ethically responsible manner (Williams et al, 2011b). There is some evidence that civil regulatory interventions can influence business practice, albeit rather weakly, and without much concern for promoting more socially responsible behaviour (Lynch-Wood and Williamson, 2013). Yet a reliance on using business case arguments for civil regulation has been questioned, not least because they are rather soft on power, and thus employers can easily disregard them (Vogel, 2010).

The second theme concerns the growing concern with characterizing the relationship between the state and civil regulation (e.g. Gunningham, 2009). Much of the existing literature on civil regulation suggests that it is dominated by the use of market campaigns, involving efforts by CSOs and their supporters to mobilize consumers to pressure corporations to alter their practices (e.g. Bendell, 2000; Gunningham, 2009; O’Rourke, 2005; Vogel, 2008). Yet research in the field of work and employment relations indicates that civil regulation is more than just a mode of transnational private governance. At national level the repertoire of civil 
regulatory interventions encompasses the use of indirect methods such as lobbying governments for changes in policy and also efforts by civil society actors to use their expertise on specific matters to act as sources of good practice and to establish the terms of the debate on which they mobilise. Civil regulation is both informed by, and in turn helps to reinforce, the increased juridification of employment relationships, functioning not as a form of purely private regulation, but as part of a complex and reflexive relationship with the regulatory efforts of the state (Williams et al, 2011b). Insights derived from such studies highlight the need for a broader conceptualization of how CSOs try to induce employers to behave in a more socially responsible fashion. This relates to the third theme, which is that the predominant way in which civil regulation is viewed - as a largely private arrangement, operating at transnational level, which relies for its effectiveness upon directly engaging with business organizations in a collaborative fashion - insufficiently captures the diversity of CSO efforts to influence business policy and practice.

For this reason, it is more appropriate to use the term 'civil governance', rather than 'civil regulation', when it comes to conceptualizing attempts by CSOs to influence the behaviour of employers. In recent years there has been a growing interest in the concept of 'governance', linked to the development of the 'regulatory state', involving efforts to steer progress towards policy goals rather than through conventional techniques of state control (e.g. Braithwaite, 2008; Steurer, 2013; Utting, 2012). New and more complex governance arrangements involve non-state actors such as CSOs (e.g. Grabosky, 2013; Levi-Faur, 2009; Levi-Faur, 2012; Reed, 2012), who play a larger part in regulating aspects of economic and social life, as part of broader 'regulatory networks' (Levi-Faur, 2009). From this perspective, efforts by non-state actors such as CSOs to influence business policy and practice constitute an 'alternative, complementary and innovative form of regulatory governance' (Levi-Faur, 
2009: 189), operating in relation to the state. Central to the political understanding of CSR is the idea that it operates as a mode of governance (Brammer et al, 2012; Moon and Vogel, 2008; Steurer, 2013), marked by the growing involvement of non-state actors, particularly firms and CSOs, 'in the democratic regulation and control of market transactions' (Scherer and Palazzo, 2011: 901). The literature on 'political' CSR, then, suggests that greater recognition of the role played by CSOs in systems of governance is needed (Baur and Arenas, 2014). Moreover, while most of the focus of existing studies has been concerned with conceptualizing developments at a transnational level, recent work attests to the importance of CSR as a mode of governance - a system of 'regulatory configurations' - at national level too (Knudsen and Moon, 2013).

Efforts by CSOs, as so-called 'new' or 'emerging' actors, to influence work and employment relations have attracted growing attention (e.g. Heery and Frege, 2006; Williams et al, 2011a; Wood and Cooke, 2014). The concept of civil governance offers an opportunity to better understand the nature of their activities. As indicated already, novel and innovative forms of private regulation at transnational level, such as labour codes of conduct, which have become prominent features of the global governance landscape, often involve input from CSOs (e.g. Bartley, 2007; Fransen and Burgoon, 2013; Donaghey et al, 2014; Locke, 2013; O’Rourke, 2005).Within national-level settings, however, much of the attention which has been devoted to the regulatory role of CSOs relates to how they give working people, particularly those in precarious employment, voice, representation and protection, mainly through efforts to influence state policy (e.g. Heery et al, 2012; Heery et al, 2014; Tapia et al, 2015). Given their location outside of employing organizations, their regulatory purchase, over matters like wage rates, is often viewed as being rather limited (Williams et al, 2011a). Moreover, the concept of 'civil regulation' has come to be used in a narrow sense, largely restricted to the 
efforts of CSOs to affect the behaviour of firms through collaborative relationships; often manifest in private transnational standard-setting arrangements. The value of 'civil governance', though, rests upon the extent to which it captures the broader ways in which CSOs seek to influence employers' policy and practice, not just directly, through collaborations with firms, but also indirectly, as part of the wider regulatory state.

\section{Researching civil governance}

The focus of our research methods was on collecting relevant data from CSOs involved in work and employment relations. Given the relative lack of existing literature on the role and activities of such organizations, a broadly exploratory research approach was favoured, with an inductive dimension, rather than addressing a set of a priori hypotheses. Our principal concern when establishing the research was to investigate how the activities of CSOs, as new and emerging actors in work and employment relations, enable workers' interests to be represented within a national-level setting, the UK in this case, both directly, through interventions aimed at working people, and also indirectly, through efforts to influence the behaviour of employers, unions and government. Nevertheless, the development of the research, including the framing of our research questions, was influenced by two areas of relevant theory. The first of these concerns the growing interest evinced in CSOs as new and emerging actors in employment relations, including work conducted on social movement and activist organisations and public interest legal organizations (e.g. Abbott, 2006). Much CSO activity is, as has already been mentioned, directed at enhancing worker representation and voice, especially manifest in efforts to influence state policy (e.g. Heery et al, 2014; Tapia et al, 2015). Moreover, the role of CSOs in influencing the policies and practices of firms, especially at transnational level, through involvement in private regulatory arrangements (e.g. codes of conduct, certification schemes), has increasingly been acknowledged (Vogel, 2010). 
Therefore the emerging literature on civil regulation, emphasizing opportunities for CSOs to strike collaborative relationships with employers, constituted the second area of existing theory which came to inform the research.

In order to realise our research aims it was considered necessary to collect data from CSOs themselves. The findings reported in this article come from two rounds of data collection from 35 UK-based CSOs who are in some way involved in the field of work and employment relations, the first in 2008 and the second in 2012. Despite making use of organizational documents in some cases (see below), we determined that the most appropriate form of data collection would be to focus on collecting data through in-depth, semi-structured interviews with key informants in multiple organizations (Kumar et al, 1993). This technique enabled us to draw on the experiences and insights of prominent respondents within CSOs, and is consistent with the 'realist' philosophical approach which informed the research. The key informant approach is particularly useful for understanding the structural mechanisms which influence policy development (Ackroyd, 2009).

Having determined our research strategy, the next key task was to identify CSOs to be included in the study. Desk-based methods were used to identify organizations which have a notable involvement in work and employment relations matters, or whose activities in some ways were designed to benefit working people. In the first phase of the research, data were generated through a series of in-depth interviews undertaken between April and July 2008 with key informants (e.g. chief executives, policy officers, project managers) from a carefully selected sample of CSOs. The choice of CSOs for the interviews was governed by a number of factors, including the need to encompass organizations whose involvement in work and employment issues seemed to be significant or interesting in some way, and also to capture 
the diversity of CSO activity. The principal types of CSO covered by the research were: health and well-being charities; work-life balance and carers' organizations; vulnerable workers' organizations (e.g. migrant workers, homeworkers); public interest legal organizations (e.g. law centres); and equality organizations of various kinds. We interviewed 50 key informants from 33 different CSOs. The questions focused on the nature of their efforts to represent the interests of working people, the scope of their regulatory activities, the manner of their relationships with other actors - employers, trade unions, government and other CSOs - the methods they use to pursue their objectives and their main achievements. We also approached potential respondents in a further 24 CSOs who either did not respond to our request for an interview, or declined to be involved.

The second round of data collection took place between March and August 2012. We approached our original contacts in the CSOs visited during 2008. Eleven of the organizations agreed to participate in this new phase of the research, and we undertook 16 indepth interviews with key informants from them, in some cases the same respondent as four years previously. We were also able to conduct two extra interviews in CSOs which had not been part of the first phase - a women's rights' organization and an additional public interest legal organization. The second set of interviews allowed us to collect further data from CSO respondents, this time focusing on the nature of the resources they use to operationalize their work and employment relations activities, the key arguments and levers deployed to advance their regulatory objectives, and respondents' own evaluation of the effectiveness of their organizations' interventions. Most importantly, however, the 2012 interviews enabled us to examine how changes in the economic and political context had affected the role and activities of CSOs and, in particular, the nature of their relationships and interactions with employers, workers, unions and government. One effect of the 2007-08 financial crisis was a 
marked economic slump in the UK, followed by a slow return to growth during 2013. Moreover, the Conservative-Liberal Democrat coalition government, which took office in May 2010, initiated a highly ambitious programme of austerity measures, involving drastic reductions in public expenditure in order to tackle the UK government's budget deficit. It also pursued an approach to work and employment relations which emphasizes the desirability of giving employers more flexibility and weakening statutory protections (Hepple, 2013). We wanted to examine how economic recession and the politics of austerity had affected the activities of CSOs in work and employment relations. How have CSOs fared in such a climate? What are the implications for understanding civil governance, and have some types fared better than others? Re-visiting some of the organizations we originally researched in 2008 allowed us to address these key questions.

table one about here

Across both phases of the research we undertook a total of 68 interviews. In some cases we were also able to make use of relevant organizational documents for the purpose of better elucidating CSO activities, supplementing the data generated by the interviews (e.g. organizational annual reports; guides for employers). See table one for details of the interviews - the type of organization covered in the research, and the position of the interviewee within the organization - and for indicative details of relevant organizational documents also analyzed during the research process.

We used the 'thematic analysis' technique for the purpose of analyzing the data from CSOs, something which emphasizes the importance of data immersion when it comes to the process of converting raw data into descriptive or explanatory conceptualization (e.g. Fereday and 
Muir-Cochrane, 2006). Thematic analysis offers the benefit of flexibility when analyzing qualitative data, yet is also a rigorous 'method for indentifying, analysing and reporting patterns (themes) within data' (Braun and Clarke, 2006: 79). The process of manual thematic analysis we used incorporated four stages. First, based on existing theory, especially that relating to new and emerging actors in employment relations, and our own inductively generated insights arising from the data-collection process, we derived four key questions for the purpose of guiding the analysis and framing the coding process. First of all, what is the purpose or rationale of regulatory intervention by CSOs? Second, what is the nature of the relationship between CSOs and other employment relations actors, namely workers, employers, trade unions and government? Third, what are the characteristic methods used by CSOs when seeking to achieve their objectives in the field of work and employment relations? And fourth, what is the nature of the ideology which informs interventions by CSOs?

These 'framing' questions informed the second stage of data analysis, which involved sorting the data into meaningful categories, through an initial process of 'holistic' coding (Saldaña, 2009). When it came to the question of the purpose of regulatory intervention, for example, these categories included: 'best practice' management of staff; improving justice for working people; promoting diversity at work; a public interest rationale; improving service provision; and enforcing employment rights. With regard to relationships with other actors, the categories included whether or not CSOs benefited from insider relationships with government, the extent to which they directly engaged with employers and negative perceptions of trade unions. As for the methods used by CSOs, these were quite varied, with categories such as: the presence of formal certification or accreditation programmes with employers; partnerships with unions; the extent and nature of government lobbying activity; 
and involvement in taking legal cases on behalf of workers. Finally, the ideological basis of CSO interventions was categorized, based upon whether or not they were rooted in a unitary, pluralist or radical conception of work and employment relationships.

Having derived relevant categories from the data, the third stage of the analysis involved linking the categories together, and establishing relations between them, akin to a type of 'pattern coding' (Miles and Huberman, 1994; Saldaña, 2009). This process took the form of generating relevant themes, which reflected patterns in the data. Among other things, these themes included: the orientation of CSOs to employers; the collective organization and mobilization of working people; advocacy on behalf of individual working people; the effects of austerity-related funding cuts; and the implications of the changing political context. The fourth and final stage of the data analysis involved reviewing and refining these themes, and identifying ways of connecting them, thus generating a distinctive set of CSO approaches. This process enables us to develop a typology which comprises four types of civil governance: the 'business-focused', 'rights-based', 'advocacy-based' and 'service-oriented' approaches respectively.

\section{Types of civil governance}

In this section we use our data to elaborate the four types of civil governance evident from the research findings.

\section{Business-focused civil governance}

The first type of civil governance identified in the research can be labelled 'businessfocused'. The main concern of this approach relates to how CSOs try to generate changes in the management of people at work by engaging directly with employers. It is an approach 
typically favoured by large, national charities. According to a respondent from a mental health charity, the organization made a decision:

"that we really wanted to upscale our work on employment, but with a focus on employers, so not just responding to government consultations and other initiatives, but actually setting our stall out and saying we wanted to work with employers directly and disseminate our best practice recommendations about how they can manage mental health in the workplace" [Mental Health and Well-Being Charity 1].

In this way, CSOs endeavour to improve the lives of working people by appealing to a corporate social responsibility ethos, or by articulating the business benefits of taking action, like better employee retention, for example, or improved productivity, thus helping to modify employers' behaviour. In the case of a leading health charity, demonstrating to employers the business benefits of retaining staff with a specific health condition had been a 'key driver' of its growing employment work. One of its officials acknowledged that having to operate with someone absent from work raised difficulties for employers:

"but you know to treat that person well will often bring about an enhanced sense of loyalty and commitment to the organisation and will hopefully in many instances enable them to return fully back to the role that they previously performed" [Health and Well-Being Charity 1].

CSOs sometimes use accreditation programmes or certification arrangements for employers as a means of securing change. Examples include schemes designed to promote best practice when it comes to managing workers with hearing impairments [Health and Well-Being 
Charity 3] and those who are pregnant [Work-Life Balance and Carers' Organization 6]. Yet such formal regulatory interventions are by no means the only way in which CSOs attempt to influence the practices of employers. Business-focused civil governance may also be marked by a more diffuse concern to influence organizational culture change. This can be viewed as a potentially more effective means of generating meaningful long-term improvements in practice. A leading work-life balance organization [Work-Life Balance and Carers' Organization 7], for example, relies upon the use of positive encouragement and awarenessraising techniques as key levers to effect change among employers. Obstacles such as managerial resistance or institutionalized ways of managing that are not receptive to flexible working, it believes, are best tackled through programmes of culture change. CSOs that pursue the 'business-focused' type of civil governance also use lobbying interventions with government to try and effect change, albeit often informed by a unitary belief in the harmony of interests between workers and employers. Contacts with trade unions, though, are rather ephemeral and transient; unions are generally not seen as a very important route for promoting positive change in organizations. Moreover, they are sometimes viewed as obstacles. For example, the head of a CSO concerned with carers found unions to be 'slippery and tricky’ [Work-Life Balance and Carers' Organization 1].

Business-focused civil governance is predicated on an organizational rationale, validated by the belief of CSOs that engaging with employers is the most effective way of achieving their goals when it comes to meeting the needs and advancing the interests of their clients or constituents as working people. For this reason, it is often rather generously funded, generally through internal reserves of income. A respondent from a leading health and well-being charity emphasized that: 'employers are not the end; they're just a route' [Health and WellBeing Organization 1]. Improving the practices of employers was viewed as the most 
effective way of achieving a CSO's objectives. According to a respondent from an organization concerned with migrant workers:

"the relationship that we're trying to have with employers is a positive one and a productive one; on the basis that if we can get some good employment practices, then it makes life better for migrant workers" [Migrants' Organization 1].

Our data show that efforts by CSOs to engage positively with employers using business case arguments to promote changes in management policy and practice are informed and validated by the public regulatory efforts of governments. CSOs often used changes in the law - such as the introduction, or extension, of anti-discrimination and equality provisions (particularly those relating to age, sexual orientation and disability) - as leverage with firms; developing their interventions, and communicating their importance to employers, on the back of the legislation. Related to this, moreover, there was an appreciation among our CSO respondents that the shadow of the law - manifest in employers' fears about the prospect of legal action by employees - exerted a strong influence over the decision of firms to engage with civil regulatory interventions. In other words, employers' receptiveness to regulatory interventions by CSOs is conditioned by the belief that, by helping to improve their practices, this diminishes the prospect of litigation.

Business-focused civil governance seems to have been largely unaffected by the economic downturn and austerity policies; indeed the CSOs that use this approach claim that their engagement with employers has grown in significance. Respondents from large charities and lobbying organizations that focus their work on engaging with employers and articulating the business benefits of regulatory interventions, claimed to be thriving. Officials from a mental 
health charity, for example, suggested that interest among employers in managing the psychological well-being of their staff had risen. Their work with employers had grown considerably. A respondent noted that:

\footnotetext{
“You’ve also got issues around constant restructures, redundancies, new employment legislation so that companies can try and get rid of people more easily; all of these things will mean that certainly we...will be busy for years. There's just going to be a massive increase in demand on our services; particularly in terms of training or even things like coaching for staff or for managers in the workplace around mental health" [Mental Health and Well-Being Charity 1].
}

Elsewhere, a respondent from an equality and diversity organization, which had seen a growth in its employment work, averred that its interventions, inasmuch as they helped to enhance employee morale and retain staff, were seen as more relevant by employers in the context of recession [LGB Rights' Organization]. Thus the research attests to the resilience of business case arguments for CSO interventions, even in a recession; but points to how they have been honed and adapted to reflect a markedly more adverse economic climate and an altered political context, which is characterized by a pronounced scepticism about the value of juridifying employment relationships.

\section{Rights-based civil governance}

Our second type of civil governance activity is concerned with advancing the interests of working people by securing better labour rights, primarily through campaigning and lobbying efforts directed at governments. The research produced some notable instances of how CSO campaigns had generated changes in government policy, for example the strengthening of 
statutory minimum wage protection for homeworkers and more rigorous age discrimination legislation. 'Rights-based' civil governance was particularly evident among CSOs that work to promote the interests, and act as the voice, of vulnerable workers, such as migrant workers and home-based workers, who trade unions can find difficult to organize. This approach to civil governance is generally marked by the absence of any notable positive engagement with employers, whose behaviour is often seen as creating the problems CSOs are trying to tackle. The purpose of regulatory intervention is to win improvements in labour rights through campaigns and lobbying efforts, in a way that often challenges the interests of employers. Although the rights-based type of civil governance encompasses efforts by CSOs to influence government policy, through lobbying efforts and responses to calls for consultation, there is often a marked scepticism evinced about the effectiveness of lobbying activity.

Rights-based civil governance tends to be marked by a concern with ensuring that workers themselves determine the priorities of CSOs, something which can be facilitated by membership structures or other mechanisms for generating grassroots influence over policy objectives. According to one of our respondents, the:

"point is [to] engage people in grassroots action that builds their connections, so the groups that might belong would be varied...but by being part of the action team they build relations with each other...trying to build across things that often divide working people" [Community Organization].

CSOs that practice this type of civil governance often operate in ways that are analogous to the work of trade unions. The head of one organization emphasized the importance of 
advancing workers' rights through collective organization and mobilization, in language redolent of the basis of trade unionism:

"if the employees gather together then they can very much influence the way in which the employer treats them; that is the whole strength of collective bargaining" [Migrants' Organization 5].

Unsurprisingly, then, CSOs that pursue a rights-based civil governance approach generally enjoy close links with, and are sympathetic to, trade unions. They were characterized as 'partners' and 'collaborators' by the head of one CSO [Migrants' Organization 3]. Respondents from organizations concerned with advancing the rights of migrant workers highlighted the union connection and their support for the positive role that unions can play in organizing them:

"the work I do, I think you could easily slot that into the department of a trade union, quite easily" [Migrants' Organization 2].

“we've made it clear that we would see the greater involvement of migrants in trade unions as being a wholly positive step forward, and that part of our role is to be able to assist in the recruitment of migrant workers" [Migrants' Organization 1].

This high level of engagement and identification with the union movement notwithstanding, CSO representatives highlighted the presence of some notable difficulties in their working relationship, not least the perceived lack of flexibility too often inherent in trade union approaches. They are sometimes seen as either too reluctant to engage with organizing 
vulnerable workers, or as lacking the imagination to think creatively about how to organize a diverse workforce more effectively. A respondent averred that unions are:

"set up on the basis that work is everything and sadly it's not anymore, so you've got to have a different model of organizing people" [Community Organization].

A related complaint is that unions are reluctant to cede authority to other organizations when it comes to joint campaign and mobilization initiatives:

"So what happens is unions will engage with these organizations on their terms for a particular campaign, but then they want to drop them, and they certainly don't want anyone else making decisions or having a key role" [Community Organization].

The effectiveness of the rights-based type of civil governance has been constrained by a changed political climate. The approach to work and employment relations taken by the Conservative-Liberal Democrat coalition government since 2010 has been dominated by the desirability of weakening the legal regulatory framework governing work and employment relations matters and promoting greater flexibility for employers (Hepple, 2013). The impact of this policy agenda has had a major effect on some CSOs:

"policy work is really, really depressing at the moment, with the political context, you just don't feel like anybody's listening, even to organizations a lot bigger than us are being ignored...with this government, we're not going to make any progress, it's going to be all about holding the line and holding on to what rights we've got...and that's a massive challenge in itself...the whole government agenda about talking about 
red tape, talking about businesses wanting deregulation, businesses wanting to hire and fire workers, all those kinds of things, it's a really difficult context...we know this government is not really interested in talking about employment rights..." (Homeworkers' Organization 2].

Funding for organizations that practice rights-based civil governance is often rather precarious. One of the CSOs we visited in 2008 had ceased to exist four years later due to a lack of finance. However, an additional challenge concerns the difficulty of operating, and trying to defend and secure improvements in the rights of working people, in a political climate which had become manifestly more hostile. The head of an organization concerned with women's health and rights at work worried that it was struggling to make an impact in such an environment. She noted that it was dealing with people in government who:

"tend to have little understanding of what's going on in other countries, and are specifically focusing on what can be done to make things as flexible - quote - as possible, notionally flexible for employers. We had a conversation with a minister, an employment minister a few months back, and yes you could see where the message came from. While there is a very strong rhetoric of the value of parenting... when you got down to tin tacks there was a very strong sense that this has got to work for business. Whereas previously we were trying to have conversations about how to achieve equality, and how to make it functional for business, that equality question seems to be very much the tap on to debates around flexibility and burdens on business, rather than the other way around" [Women's Rights' Organization].

\section{$\underline{\text { Advocacy-based civil governance }}$}


The rights-based approach is marked by an emphasis on the use by CSOs of lobbying and campaigning efforts designed to secure improvements in labour rights, and underpinned by collective organization and mobilization. Our third type - advocacy-based civil governance is also concerned with labour rights, but with a focus on ensuring that working people are effectively represented, generally on an individual basis, so that these rights are enforced. CSO activity involves advising, representing and litigating on behalf of individual workers as a means of trying to guarantee their rights at work. Largely pursued by public interest legal organizations such as law centres this form of civil governance is concerned with using the law to pursue the rights of individual working people directly, thus implicitly challenging the interests of employers. This approach can be viewed as a type of civil governance because of the extent to which (the potential for) litigation encourages employers to comply with legal obligations, thus causing them to amend their behaviour. It also encompasses the provision of advice and guidance to working people, relating to their rights and entitlements, covering matters such as whistleblowing, specific health problems and aspects of discrimination law, depending upon the orientation of the CSO in question. There is sometimes a concern with empowering workers, so that they are better able to assert their employment rights.

While there is evidence that some CSOs using this approach have established relationships with employers - including the provision of training and awareness-raising interventions for the most part the emphasis is on upholding relationships with individual workers. Organizations that pursue advocacy-based civil governance often evince a marked degree of cynicism towards employers, concerned about the tendency for supposedly 'good' employment practices to be used to legitimize business goals, and not for improving the treatment of workers. Advocacy-based civil governance is often justified on the basis of a 
public interest rationale; ensuring that laws are upheld, and that people's statutory employment rights are protected appropriately.

Although, of course, legislation provides the rationale for this kind of civil governance activity, CSOs that practice it are rarely involved themselves in lobbying government, though they may respond to relevant government consultation exercises. There is, however, more evidence of a relationship with trade unions, including client referrals where appropriate. Yet an emphasis on representing workers as individuals can sometimes lead to tensions as unions have to take the collective interests of workers into account. CSOs must take care not to antagonize unions, for example by being seen as too eager to take on cases in a way that usurps their role. The relationship between organizations that practice advocacy-based civil governance and the trade unions is generally a positive and mutually beneficial one; however, respondents from CSOs did express concerns about what they saw as the poor quality of representation sometimes offered by unions, and the frustration they felt at not being able to intervene:

"A big problem is we get a lot of enquiries from people who are not satisfied with their attempts to get help from their own trade union, but we still don't think that's our role to fill that gap. So that's quite painful to say to someone, we're not helping you, even though from listening to them you know they're not getting proper help, but we're not funded to do that" [Public Interest Legal Organization 3].

Unlike rights-based civil governance, which has been rendered less effective by a changed political climate that privileges employers' flexibility, the principal constraint upon the effectiveness of the advocacy-based approach concerns the adverse impact of substantial 
austerity-driven funding cuts. Public interest legal organizations are often highly reliant upon the state for funding, through legal aid budgets or local government authorities. However, demand from workers for support has grown, at a time when the capacity of CSOs to provide representational services has markedly declined. By engendering a more constrained financial climate, the economic downturn and, in particular, government austerity policies seem to have encouraged the greater use of coalition and joint working arrangements. CSOs have engaged in more collaborative work, pooling resources and expertise, in the context of major cuts to funding. This has been a pronounced trend among public interest legal organizations, especially law centres and the like, most of which have experienced substantial financial cutbacks arising out of reduced levels of support from local authorities and other funders, and reductions in legal aid budgets. The increasingly constrained financial regime means that some CSOs, particularly those concerned with providing working people with legal support and representation, have reduced capacity, at the same time as demand for their services has grown because of the economic slump. Respondents expressed frustration that they had to take on fewer employment cases as a result. One observed that:

"To organizations like us the problem is the funding is disappearing and all the partnership organizations are disappearing, so money is just draining out of the system with an enormous glugging sound, because legal aid is being massively cutback in scope and the way it is provided" [Public Interest Legal Organization 1].

\section{$\underline{\text { Service-oriented civil governance }}$}

The fourth type of civil governance highlighted by this research is characterized by an emphasis on providing working people with employment-related services, particularly relating to employability and labour market integration. The principal concern of such 
'service-oriented' civil governance is with using project and contract-based funding, particularly from government and other agencies, to support specific groups of workers, such as migrant workers, and improving their access to, and experience of, employment opportunities. The motivation for regulatory intervention is rooted in an integrationist rationale. Efforts by CSOs to enact the service-oriented type of civil governance are often designed to enable vulnerable workers to integrate more effectively into the labour market. There are also women's organizations which focus on professional career development activities.

The research produced some prominent examples of this type of civil governance. One of the carers' organizations was involved in a project alongside local government authorities and other CSOs designed to enhance the employment prospects of people with caring responsibilities [Work-Life Balance and Carers' Organization 1]. An organization representing single parents had taken part in something similar [Work-Life Balance and Carers' Organization 5]. A CSO involved with migrants, refugees and asylum-seekers ran a government-funded project designed to provide clients with individual support services, especially in relation to the labour market. One of its officials noted that a lot of the work is:

“either explicitly or implicitly would be about employment, or [if] it's not explicitly about employment, it would be getting someone to the stage where they could be employed" [Migrants' Organization 4].

Disability charities often receive European Union and UK government funds to deliver employment services to clients whose conditions meant that they came within their respective remits [e.g. Health and Well-Being Charity 3]. Not all service provision, however, is funded 
by the state and state agencies; in some cases CSOs use other sources of funds, including their own reserves, for the purpose of developing initiatives designed to improve the labour market outcomes of specific categories of workers. A good illustration of this in practice concerns the efforts made by women's organizations to provide networking, mentoring and other interventions aimed at enhancing labour market participation [e.g. Women's Organization 2].

In this respect, then, CSOs that pursue a service-oriented civil governance approach, often, albeit not always, act as a sub-contractor to the government and its agencies. There is often a notable emphasis on building relationships with state agencies, and accessing relevant funding streams. Any relationships struck with employers derive from this orientation; for example, the provision of work placement opportunities and training and development interventions. A key challenge for the CSOs engaged in this kind of governance activity concerns the need to balance the tension that arises between their dependency upon state funds for labour market projects and services and a concern with promoting the rights of workers which often makes them highly critical of government policy. Moreover, an overdependence on state funds may be a source of potential vulnerability, stimulating an interest in alternative sources of income.

Service-oriented civil governance has been markedly affected by austerity policies, with reduced levels of funding meaning that many CSOs have had to wind up projects and rationalize their services, often resulting in staff cuts. As a result, some have looked to diversify their sources of funding, so that they are less reliant on support from state agencies. A respondent from an organization that supports migrant workers, refugees and asylum seekers explained that: 
"One of our kind of underlying strategic aims is to move away from dependency on UKBA [United Kingdom Border Agency] funding and so we're trying to build relationships with other government departments, local authorities, trust funds, we're building up our support and donor base at the moment. I guess increasingly we felt that...our kind of strategic aims no longer intersect as much as they did before" [Migrants' Organization 4].

A respondent from another CSO highlighted the necessity of organizations coming together to pool resources, and thus operate more effectively; something which to his mind had resulted in some positive consequences. With regard to support and advocacy for migrant workers, refugees and asylum-seekers, he observed that:

'there's a real sense of groups trying to come together to tackle the problems that are being thrown up by the cuts in resources, the changes in policy all of those kinds of things...at the moment there's a sense of, quite a kind of buzz of excitement, because we're all coming up with ideas, we're trying to think about the best ways of working together, we're coming up with models that are much more cost effective than we were probably ever able to manage before. But I think there is also continuing to be this risk that survival pulls you back into your own organization...so for me it's about are there constructive partnerships that we can run, we can set up with other refugee, community organisations around supporting people around employment and that's something we're looking into at the moment" [Migrants' Organization 5]. 
In summary, then, these findings demonstrate that four types of civil governance are evident in work and employment relations - see table two for an overview. Whereas the businessfocused approach seems to have been unaffected by recession and the climate of austerity, government funding cuts have markedly undermined the capacity of CSOs to deliver advocacy-based and service-oriented civil governance respectively. The efficacy of rightsbased civil governance however, has been weakened more by the presence of an unsympathetic political climate.

table two about here

\section{Conclusion: interpreting civil governance}

There has been growing interest in the methods used by CSOs to influence business policy and practice, manifest in the concept of civil regulation (e.g. Bendell, 2000; Gunningham, 2009; Newell, 2008; Zadek, 2007). This concerns how CSO interventions induce corporations to behave in a more socially responsible manner (e.g. Vogel, 2008; Vogel, 2010). Although some studies have examined the important extent to which civil regulation interacts with the public regulatory efforts of governments (e.g. Williams et al, 2011b), it is generally viewed as a private regulatory approach, evident particularly at transnational level, where it is seen as helping to fill the regulatory gap that has arisen under globalization. Civil regulation is often conceptualized in rather a narrow way, restricted to understanding the influence of non-statutory norms, codes and standards of good business practice generated by CSOs (Levi-Faur, 2009), centred upon the use of business case arguments to drive changes in the behaviour of employers, and underpinned by market campaigns which mobilize consumers (e.g. Bendell, 2000; Gunningham, 2009; Vogel, 2008). 
There have been calls for issues pertaining to regulation to be given more attention in the wider business ethics literature (Norman, 2011). Moreover, efforts by CSOs to induce firms to behave in a more socially responsible manner are increasingly coming to be interpreted through a governance lens (e.g. Scherer and Palazzo, 2011). An important contribution of this article, though, is to highlight the importance of developing a broader conceptualization of the way in which CSOs attempt to influence business policy and practice, centred upon the concept of 'civil governance'. It recognizes that CSOs not only attempt to shape the behaviour of employers through the forging of direct, collaborative relationships, but also do so indirectly, with interactions of various kinds with the state being integral. Building on existing work on 'political CSR', which recognizes the role played by CSOs in systems of governance (Baur and Arenas, 2014), our conceptualization of civil governance offers a broader and more encompassing approach to understanding how civil society actors influence the policies and practices of employers than is the case with the often rather narrowly-focused emphasis on civil regulation. The research findings, by highlighting the existence of different types of civil governance, point to the distinctive ways in which CSOs exercise influence over employers' behaviour, through different modes of interaction with firms, working people, unions and government, offering an insight into the nature of national-level 'regulatory configurations' (Knudsen and Moon, 2013). They demonstrate that CSOs do not function simply as regulatory institutions, but also operate as part of broader systems of labour governance, through efforts to induce corporations to behave in a more socially responsible manner within the ambit of the regulatory state.

Four types of civil governance were identified in the research. What we term 'businessfocused' civil governance involves the use by CSOs of business case arguments for employing and managing people at work in a socially responsible manner when engaging 
directly with firms. In some ways, this type can be viewed as analogous to the existing conceptualization of civil regulation. However, by no means should business-focused civil governance be viewed as a purely 'private' mode of regulatory activity, given the extent to which CSOs that use it rely upon statutory provisions to validate their engagement with employers, and as a lever to promote 'best practice' in employment. The second type of civil governance identified by the research - the 'rights-based' approach - concerns campaigning and lobbying efforts by CSOs to secure improvements in labour rights, underpinned by a belief in the desirability of promoting independent collective organization and mobilization by workers. The third type of civil governance identified by the research is the 'advocacybased' approach. This refers to efforts by CSOs - often public interest legal organizations to ensure that existing labour rights are better enforced, and employers comply with them. Advocacy-based civil governance is often justified with reference to a public interest rationale, in the sense that there is an imperative to promote better enforcement of, and compliance with, legal provisions, better enabling workers to assert their statutory rights. Finally, our fourth type of civil governance - the 'service-oriented' approach - relates to efforts by CSOs to influence employers' behaviour through the use of training, development and employability interventions. These are often - but not exclusively - funded largely by state agencies, for the purpose of promoting the policy objective of greater labour market integration.

We do not suggest that each of these types of civil governance is necessarily incompatible with any of the others; indeed some CSOs pursue more than one of them. One of the mental health charities visited during the research, for example, operates three streams of work: engaging with employers to help them understand the business benefits of employing people with mental health problems and of improving the way in which they are managed (business- 
focused civil governance); using legal test cases to improve the effectiveness of statutory anti-discrimination provisions (advocacy-based civil governance); and providing services to people with mental health problems to enable them to participate in the labour market (service-oriented civil governance). Some CSOs varied the approach taken according to the focus of activity. For example, a leading community organization which featured in the research uses business case arguments when dealing directly with employers (businessfocused civil governance), at the same time as working to mobilize people to participate in 'living wage' campaigns against some firms (rights-based civil governance).

Why is it important to recognize that CSOs can embody multiple types of civil governance? We already know about the range of different strategies and methods of engagement between CSOs and business organizations that exist (Burchell and Cook, 2013), including aspects of confrontation as well as collaboration (Arenas et al, 2013). Our findings, though, highlight the factors that induce CSOs to adopt different types of civil governance. Importantly, they are not conditioned by the type of worker a CSO is trying to support; rather, the strategic objectives of the organization in question, and, related to this, the nature of its funding, are more important influences. Service-oriented civil governance, for example, is largely predicated on the availability of contract-based funding from the government and state agencies. Some of the larger health charities have been able to engage in business-focused civil governance activities because the strength of their income reserves has enabled them to invest in innovative ways of supporting working people as a means of realizing their broader objectives. A further point is that it can be difficult to distinguish between different varieties of civil governance in practice, since there is inevitably some degree of overlap. For example, legal cases brought by CSOs to test a particular area of employment law are clearly a manifestation of advocacy-based civil governance; yet such interventions can validate efforts 
to challenge, and perhaps mobilize workers against, the interests of employers, and thus are more reflective of a rights-based approach.

Our research findings also indicate that national-level changes in the economic and political contexts can affect the efficacy of some types of civil governance. The impact of economic recession and the altered political climate, dominated by austerity-driven reductions in public expenditure and a preference for weakening statutory employment protections, point to the differing fortunes of each type of civil governance. While business-focused civil governance was largely unaffected, the potency of the other types was markedly undermined, albeit for different reasons. Much service-oriented and advocacy-based civil governance is dependent upon the provision of state funds, to operate employability projects, for example, or to support the work of public interest legal organizations. The policy of austerity, by markedly depleting the amount of resources available, meant that CSOs undertaking such activities were required to scale back their operations. The efficacy of rights-based civil governance, though, was undermined more because a change in government rendered the state less receptive to campaigns to improve labour standards. Business-focused civil governance was more resilient, not only because it is less dependent on the state for support, but also because the economic recession, and its consequences, had generated challenges for employers (e.g. maintaining the psychological well-being of their staff) that CSOs positioned themselves to address.

The research findings also have implications for conceptualizing the role of CSOs which, as new and emerging actors in work and employment relations (Heery and Frege, 2006; Williams et al, 2011a; Wood and Cooke, 2014), is often conceived largely as concerning the provision of voice and representation to workers in precarious part of the labour market, 
particularly by means of lobbying and campaigning activities designed to influence public policy (Heery et al, 2012; Heery et al, 2014; Tapia et al, 2015). This political orientation reflects the lack of direct regulatory leverage enjoyed by CSOs over matters such as wage rates. Nevertheless, studies of regulation highlight how collaboration between CSOs and employing organizations can influence corporate policy and practice (e.g. Williams et al, 2011b), including at transnational level (e.g. Todd Beer et al, 2012). A key contribution of this article, however, is to extend our understanding of the role of CSOs in work and employment relations by demonstrating that they do not function merely as regulatory institutions but operate as part of, and make a contribution to, broader systems of labour governance within states. The typology is important because it shows that there is more than one approach taken by CSOs to pursuing civil governance. It provides insights into the different methods they use in their efforts to influence employers' behaviour, both directly and indirectly, either through, or in relation to, the state. Their lobbying and campaigning activities, their efforts to represent working people and provide them with voice, their service provision and their interventions designed to influence employers' behaviour can all be conceptualized as manifestations of different kinds of civil governance, based on various types of relationship with the state. Although work on private and civil regulation recognizes the importance of the state (e.g. Bartley, 2007; Gunningham, 2009; Williams et al, 2011b), the approach we take to demonstrating how CSOs try to influence labour standards within national settings, by focusing on civil governance, provides an integrated, and thus more satisfactory way of conceiving their role, in a way that addresses calls for studies which extend the conceptual terrain of work and employment relations (e.g. Tapia et al, 2015).

Existing general work on regulatory innovation points to the importance of sector-specific issues and challenges, while recognizing the presence of some broad common features (e.g. 
Levi-Faur, 2009). The key insight from this research, which is that efforts by CSOs to influence business policy and practice should be interpreted through the lens of civil governance regimes, involving various patterns of interaction between CSOs, workers, employers, unions and, perhaps most importantly, governments, is of wider relevance to scholars who work at the interface of regulation, governance and CSR. To a large extent, the four-fold typology of civil governance elaborated in this article is specific to the field of work and employment relations. However, the business-focused type is no doubt evident elsewhere, given its parallels with existing conceptualizations of civil regulation; while the service-oriented approach will be relevant in some areas of social policy (e.g. Damm, 2014). Moreover, CSOs working in the field of human rights, and those involved in environmental campaigning, are also likely to be involved in aspects of 'rights-based' and 'advocacy-based' civil governance. Further research studies are needed, particularly in other fields and national settings, to shed light on the nature of civil governance in different sectors and environments, based on, and helping to refine, the typology developed here.

\section{Acknowledgements}

The research on which this paper is based was funded by the Nuffield Foundation and Kingston University. We thank the reviewers for their extensive comments on earlier versions of the paper, their helpful suggestions and their encouragement.

\section{References}

Abbott, B. (2006). Determining the significance of the Citizens Advice Bureau as an industrial relations actor. Employee Relations, 28(5), 435-448. 
Ackroyd, S. (2009). Research designs for realist research. In D. A. Buchanan and A. Bryman (eds.), The SAGE Handbook of Organizational Research Methods (pp.532-548), SAGE, London.

Arenas, D., Sanchez, P. and Murphy, M. (2013). Different paths to collaboration between businesses and civil society and the role of third parties. Journal of Business Ethics 115 (4), 723-739.

Ayres, I. and Braithwaite, J. (1992). Responsive Regulation: Transcending the Deregulation Debate. Oxford University Press, Oxford.

Bartley, T. (2003). Certifying forests and factories: states, social movements, and the rise of private regulation in the apparel and forest products fields. Politics and Society 31 (3), 433464.

Bartley, T. (2007). Institutional emergence in an era of globalization: the rise of transnational private regulation of labor and environmental conditions. American Journal of Sociology 113 (2), 297-351.

Bartley, T. (2011). Certification as a mode of social regulation. In D. Levi-Faur (ed.), Handbook on the Politics of Regulation (pp.441-452), Edward Elgar, Cheltenham.

Bartley, T. and Child, C. (2014). Shaming the corporation: the social production of targets and the anti-sweatshop movement. American Sociological Review 79 (4), 653-679. 
Baur, D. and Arenas, D. (2014). The value of unregulated business-NGO interaction: a deliberative perspective. Business and Society 53 (2), 157-186.

Baur, D. and Schmitz, H. P. (2012). Corporations and NGOs: when accountability leads to co-optation. Journal of Business Ethics, 106, 9-21.

Bendell, J. (2000). Terms for Endearment: Business, NGOs and Sustainable Development. Greenleaf Publishing, Sheffield.

Braithwaite, J. (2008). Regulatory Capitalism. Edward Elgar, Cheltenham.

Brammer, S., Jackson, G. and Matten, D. (2012). Corporate social responsibility and institutional theory: new perspectives on private governance. Socio-Economic Review 10, 328.

Braun, V. and Clarke, V. (2006). Using thematic analysis in psychology. Qualitative Research in Psychology 3 (2), 77-101.

Burchell, J. and Cook, J. (2013). CSR, co-optation and resistance: the emergence of new agonistic relations between business and civil society. Journal of Business Ethics 115 (4), 741-754.

Chan, S. and Pattberg, P. (2008). Private rule-making and the politics of accountability: analyzing global forest governance. Global Environmental Politics 8 (3), 103-121. 
Damm, C. (2014). A mid-term review of third sector involvement in the Work Programme. Voluntary Sector Review 5 (1), 97-116.

den Hond, F. and de Bakker, F. (2007). Ideologically motivated activism: how activist groups influence corporate social change activities. Academy of Management Review 32 (3), 901924.

Donaghey, J., Reinecke, J., Niforou, C. and Lawson, B. (2014). From employment relations to consumption relations: balancing labor governance in global supply chains. Human Resource Management 53 (2), 229-52.

Egels-Zandén, N. (2007). Suppliers' compliance with MNCs' codes of conduct: behind the scenes at Chinese toy suppliers. Journal of Business Ethics 75 (1), 45-62.

Esbenshade, J. (2004). Monitoring Sweatshops: Workers, Consumers and the Global Apparel Industry. Temple University Press, Philadelphia PA.

Esbenshade, J. (2012). A review of private regulation: codes and monitoring in the apparel industry. Sociology Compass 6-7, 541-556.

Everett, J., Neu, D. and Martinez, D. (2008). Multi-stakeholder labour monitoring organizations: egoists, instrumentalists, or moralists? Journal of Business Ethics 81 (1), 117142. 
Fereday, J. and Muir-Cochrane, E. (2006). Demonstrating rigour using thematic analysis: a hybrid approach of inductive and deductive coding and theme development. International Journal of Qualitative Methods 5 (1), 80-92.

Fransen, L. (2012). Corporate Social Responsibility and Global Labor Standards: Firms and Activists in the Making of Private Regulation. Routledge, Abingdon.

Fransen, L. (2013). Global companies and the private regulation of global labor standards. In J. Mikler (ed.), The Handbook of Global Companies (pp.437-455), John Wiley, Chichester.

Fransen, L. and Burgoon, B. (2012). A market for worker rights: explaining business support for international private labour regulation. Review of International Political Economy 19 (2), 236-266.

Fransen, L. and Burgoon, B. (2013). Global labour-standards advocacy by European civil society organizations: trends and developments. British Journal of Industrial Relations, early view, DOI:10.1111/bjir.12017

Gond, J-P., Kang, N. and Moon, J. (2011). The government of self-regulation: on the comparative dynamics of corporate social responsibility. Economy and Society 40 (2), 640671.

Grabosky, P. (1995). Using non-governmental resources to foster regulatory compliance. Governance 8 (4), 527-550. 
Grabosky, P. (2013). Beyond Responsive Regulation: the expanding role of non-state actors in the regulatory process. Regulation and Governance 7, 114-123.

Gulbrandsen, L. (2010). Transnational Environmental Governance: the Emergence and Effects of the Certification of Forests and Fisheries. Edward Elgar: Cheltenham.

Gunningham, N. (2009). Environmental law, regulation and governance: shifting architectures. Journal of Environmental Law 21 (2), 179-212.

Heery, E. and Frege, C. (2006). New actors in industrial relations. British Journal of Industrial Relations 44 (4), 601-4.

Heery, E., Abbott, B. \& Williams, S. (2012). The involvement of civil society organizations in British industrial relations: extent, origins, significance. British Journal of Industrial Relations, 50(1), 47-52

Heery, E., Abbott, B. \& Williams, S. (2014). Civil society organizations and employee voice. In A. Wilkinson, J. Donaghy, T. Dundon \& R.B. Freeman (Eds.), Handbook of research on employee voice (pp.208-223). Cheltenham, Edward Elgar.

Hepple, B. (2013). Back to the future: employment law under the coalition government. Industrial Law Journal 42 (3), 203-223.

Hutter, B. (2006). The Role of Non-state Actors in Regulation. ESRC Centre for Analysis of Risk and Regulation, Discussion Paper No.37, London. 
Hutter, B. and O’Mahony, J. (2004). The Role of Civil Society Organisations in Regulating Business. ESRC Centre for Analysis of Risk and Regulation, Discussion Article No.26, London.

Kneip, V. (2013). Protest campaigns and corporations: cooperative conflicts? Journal of Business Ethics 118, 189-202.

Knudsen, J. S. (2013). The growth of private regulation of labour standards in global supply chains: mission impossible for Western small- and medium-sized firms? Journal of Business Ethics 117 (2), 387-398.

Knudsen, J. S. and Moon, J. (2013). The regulatory configurations of political CSR: international interactions of business, civil society and government. Civil Society and Government Working Paper, http://papers.ssrn.com/sol3/papers.cfm?abstract_id=2234444

Kumar, N., Stern, L. W. and Anderson, J. C. (1993). Conducting interorganizational research using key informants. Academy of Management Journal 36 (6), 1633-1651.

Levi-Faur, D. (2009). Regulatory capitalism and the reassertion of the public interest. Policy and Society 27 (3), 181-191.

Levi-Faur, D. (2012). From 'Big Government' to 'Big Governance’? In D. Levi-Faur (ed.), The Oxford Handbook of Governance (pp.3-18), Oxford University Press, Oxford. 
Locke, R. (2013). The Promise and Limits of Private Power: Promoting Labor Standards in a Global Economy. Cambridge University Press, Cambridge.

Lynch-Wood, G. and Williamson, D. (2013). Civil regulation, the environment and the compliance orientations of SMEs. Journal of Business Ethics DOI: 10.1007/s10551-013$1925-6$

Matten, D. and Moon, J. (2008). 'Implicit' and 'explicit' CSR: a conceptual framework for a comparative understanding of corporate social responsibility. Academy of Management Review 33 (2), 404-424.

Miles, M. N. and Huberman, M. A. (1994). Qualitative Data Analysis: an Expanded Sourcebook. ( $2^{\text {nd }}$ edition), SAGE, Thousand Oaks CA.

Moon, J. and Vogel, D. (2008). Corporate social responsibility, government and civil society. In A. Crane, A. McWilliams, D. Matten, J. Moon and D. Siegel (eds.), The Oxford Handbook of Corporate Social Responsibility (pp.305-323), Oxford University Press, Oxford.

Newell, P. (2008). Civil society, corporate accountability and the politics of climate change. Global Environmental Politics 8 (3), 122-153.

Norman, W. (2011). Business ethics as self-regulation: why principles that ground regulations should be used to ground beyond-compliance norms as well. Journal of Business Ethics 102 (1), 43-57. 
O’Rourke, D. (2003). Outsourcing regulation: analyzing nongovernmental systems of labor standards and monitoring. Policy Studies Journal 31 (1), 1-29.

O’Rourke, D. (2005). Market movements: nongovernmental organization strategies to influence global production and consumption. Journal of Industrial Ecology 9 (1-2), 115-128.

Pattberg, P. (2005). The institutionalization of private governance: how business and nonprofit organizations agree on transnational rules. Governance 18 (4), 589-610.

Reed, D. (2012). Development and the problematic of non-state regulation. In A. MukherjeeReed, D. Reed and P. Utting (eds.), Business Regulation and Non-State Actors: Whose Standards? Whose Development? (pp.19-38), Routledge, Abingdon.

Saldaña, J. (2009). The Coding Manual for Qualitative Researchers. London: SAGE.

Scherer, A. G. and Palazzo, G. (2007). Toward a political conception of corporate responsibility - business and society seen from a Habermasian perspective. Academy of Management Review 32 (4), 1096-1120.

Scherer, A. G. and Palazzo, G. (2011). The new political role of business in a globalized world: a review of a new perspective on CSR and its implications for the firm, governance, and democracy. Journal of Management Studies 48 (4), 899-931.

Seidman, G. (2007). Beyond the Boycott: Labor Rights, Human Rights and Transnational Activism. Russell Sage Foundation, New York. 
Steurer, R. (2013). Disentangling governance: a synoptic view of regulation by government, business and civil society. Policy Sciences 46 (4), 387-410.

Tapia, M., Ibsen, C. and Kochan, T. (2015). Mapping the frontier of theory in industrial relations: the contested role of worker representation. Socio-Economic Review 13 (1), 157-84.

Todd Beer, C., Bartley, T. and Roberts, W. (2012). NGOs: between advocacy, service provision and regulation. In D. Levi-Faur (ed.), The Oxford Handbook of Governance (pp.325-338), Oxford University Press, Oxford.

Utting, P. (2005). Corporate responsibility and the movement of business. Development in Practice 15 (3-4), 375-88.

Utting, P. (2012). Activism, business regulation and development. In A. Mukherjee-Reed, D. Reed and P. Utting (eds.), Business Regulation and Non-State Actors: Whose Standards? Whose Development? (pp.38-53), Routledge, Abingdon

Vogel, D. (2005). The Market for Virtue. ( $2^{\text {nd }}$ edition), Brookings Institution Press, Washington DC.

Vogel, D. (2008). Private global business regulation. Annual Review of Political Science 11, 261-282. 
Vogel, D. (2010). The private regulation of global corporate conduct: achievements and limitations. Business and Society 49 (1), 68-87.

Wells, D. (2007). Too weak for the job: corporate codes of conduct, non-governmental organizations and the regulation of international labour standards. Global Social Policy 7 (1), $51-74$.

Williams, S., Abbott, B., \& Heery, E. (2011a). New and emerging actors in work and employment relations: the case of civil society organisations. In K. Townsend \& A. Wilkinson (Eds.), The Edward Elgar research handbook on work and employment relations (pp.130-149). Cheltenham: Edward Elgar.

Williams, S., Heery, E. \& Abbott, B. (2011). The emerging regime of civil regulation in work and employment relations. Human Relations, 64(7), 951-970.

Wood, G. and Cooke, F-L. (2014). New actors in employment relations. In A. Wilkinson, G. Wood and R. Deeg (eds.), The Oxford Handbook of Employment Relations: Comparative Employment Systems (pp.683-700), Oxford, Oxford University Press.

Yaziji, M. and Doh, M. (2009). NGOs and Corporations: Conflict and Collaboration. Cambridge University Press, Cambridge.

Zadek, S. (2007). The Civil Corporation. (2 ${ }^{\text {nd }}$ edition), Earthscan, London. 
Table one: details of CSOs covered by the research, respondents and documentation

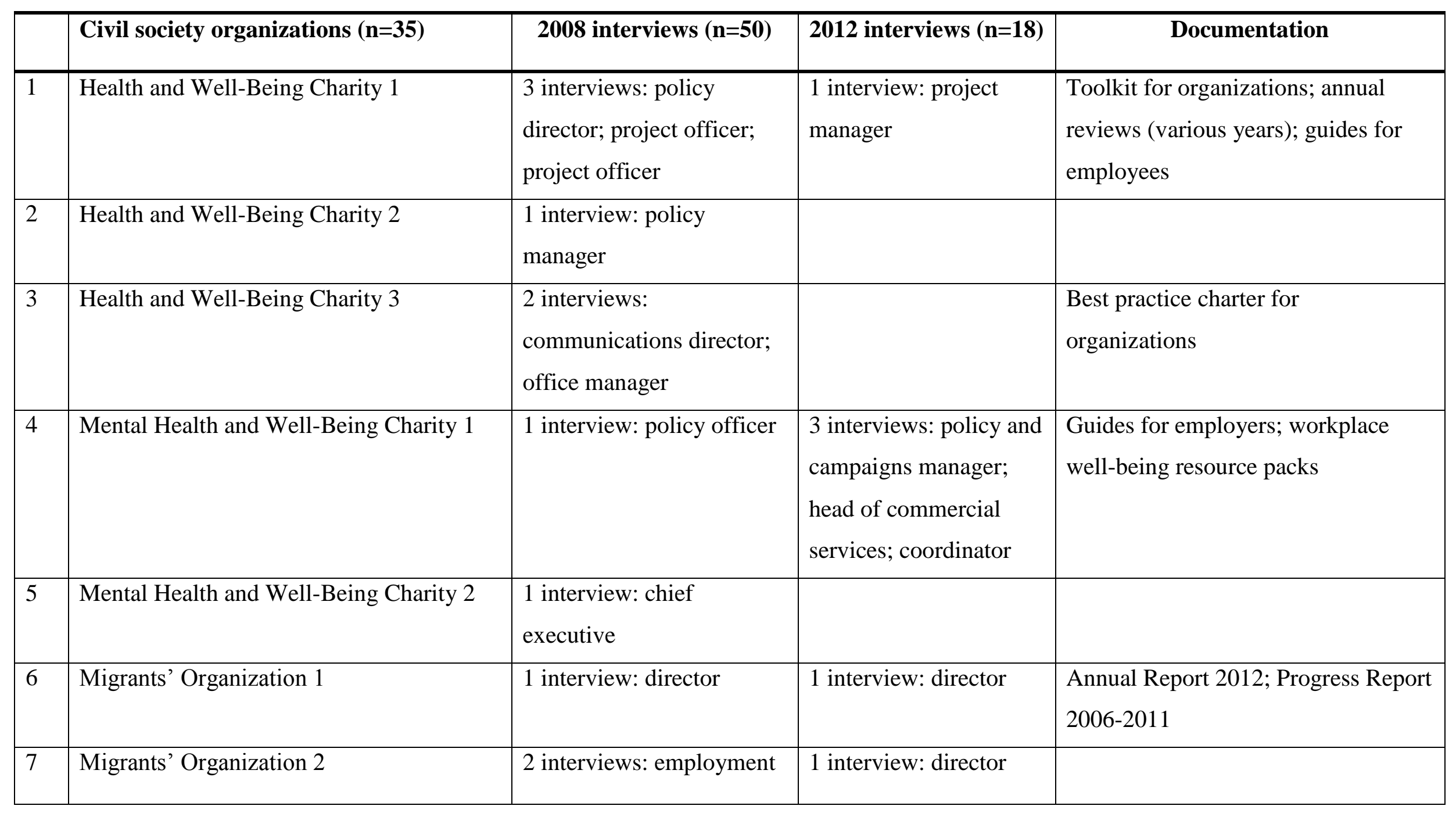




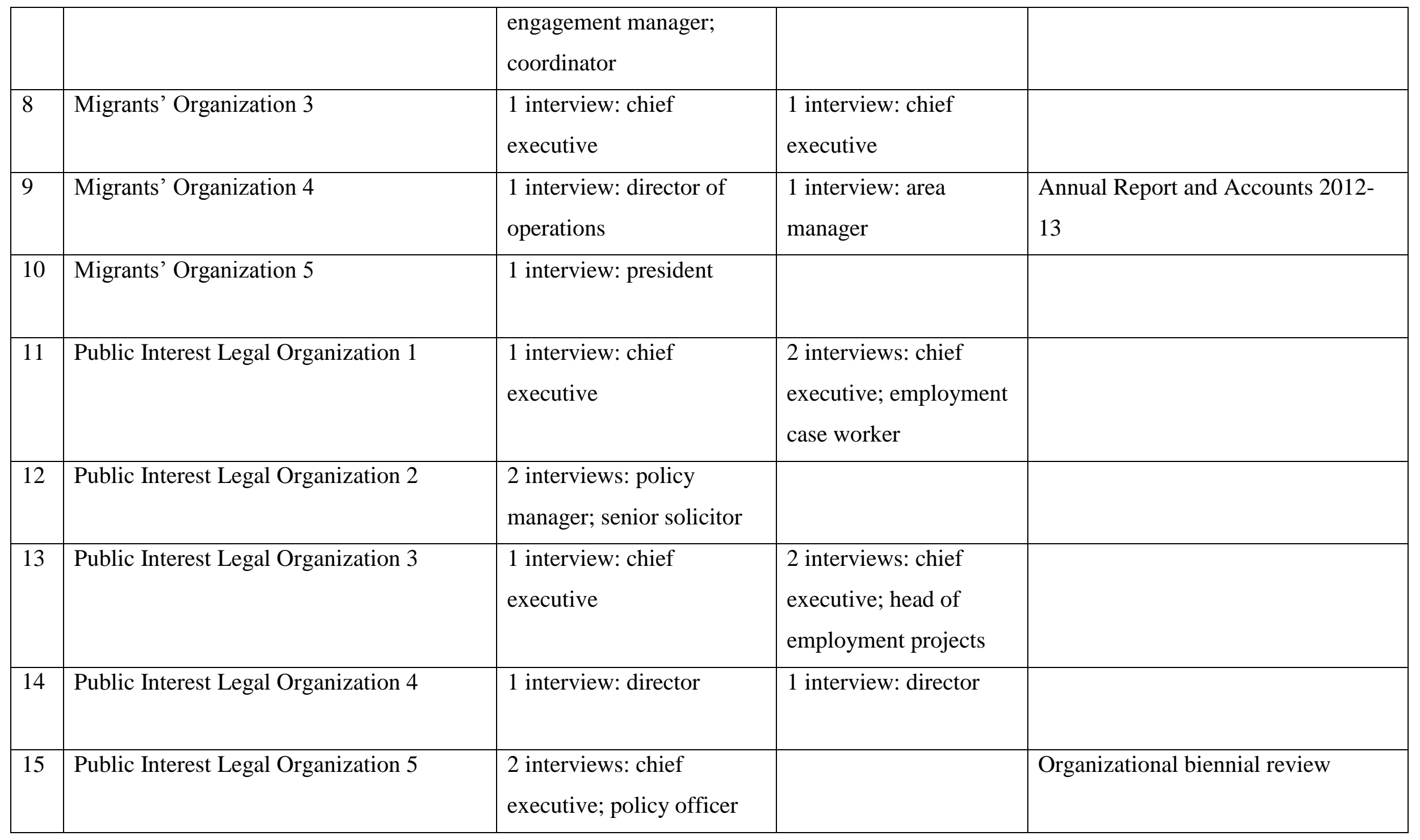




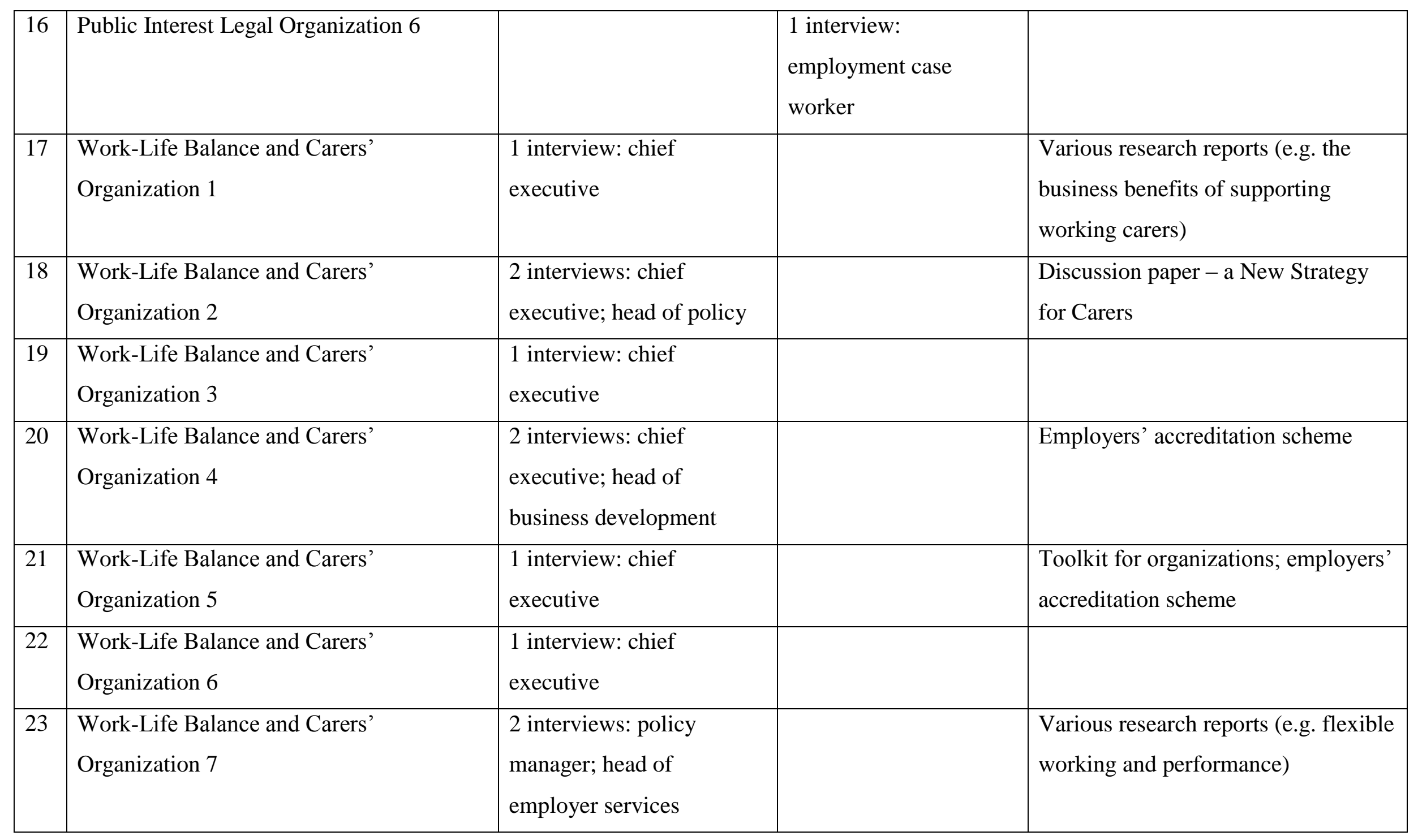




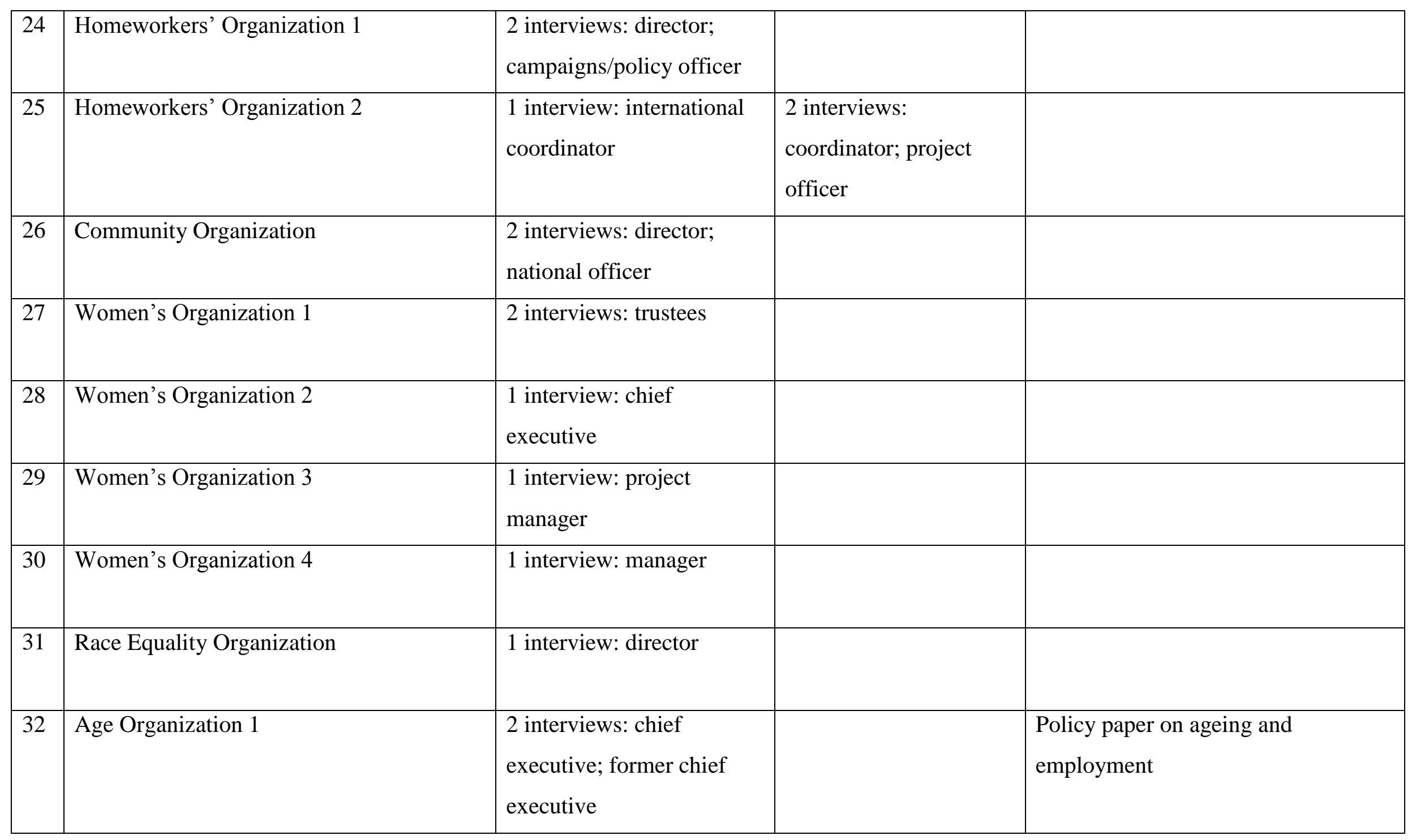




\begin{tabular}{|l|l|l|l|l|}
\hline 33 & Age Organization 2 & $\begin{array}{l}3 \text { interviews: head of } \\
\text { policy; project manager; } \\
\text { project manager }\end{array}$ & \\
\hline 34 & $\begin{array}{l}\text { Lesbian, Gay and Bisexual (LGB) Rights' } \\
\text { Organization }\end{array}$ & $\begin{array}{l}3 \text { interviews: chief } \\
\text { executive; director of } \\
\text { workplace programmes; } \\
\text { workplace officer }\end{array}$ & $\begin{array}{l}\text { 1 interview: deputy } \\
\text { chief executive }\end{array}$ & $\begin{array}{l}\text { Employers' toolkit; guides to } \\
\text { engaging gay people at work }\end{array}$ \\
\hline 35 & Women's Rights' Organization & & 1 interview: director & Annual Report 2011-12 \\
\hline
\end{tabular}


Table two: types of civil governance

\begin{tabular}{|c|c|c|c|c|c|c|c|}
\hline & Orientation & $\begin{array}{l}\text { Focus of } \\
\text { activity }\end{array}$ & $\begin{array}{l}\text { Relations with } \\
\text { employers }\end{array}$ & $\begin{array}{c}\text { Relations with } \\
\text { the state and } \\
\text { government }\end{array}$ & $\begin{array}{c}\text { Relations with } \\
\text { trade unions }\end{array}$ & Funding & Rationale \\
\hline $\begin{array}{l}\text { 'Business- } \\
\text { focused' }\end{array}$ & Employers & $\begin{array}{l}\text { Influencing how } \\
\text { people are } \\
\text { managed at } \\
\text { work, based on a } \\
\text { unitary frame of } \\
\text { reference }\end{array}$ & $\begin{array}{l}\text { Positive, centred } \\
\text { upon the } \\
\text { business } \\
\text { benefits of } \\
\text { taking action }\end{array}$ & $\begin{array}{l}\text { Interventions } \\
\text { informed and } \\
\text { validated by } \\
\text { government } \\
\text { legislation }\end{array}$ & $\begin{array}{l}\text { Unions viewed } \\
\text { as unimportant }\end{array}$ & $\begin{array}{l}\text { Generally well- } \\
\text { funded through } \\
\text { internal reserves }\end{array}$ & 'Organizational' \\
\hline 'Rights-based' & $\begin{array}{l}\text { Collective } \\
\text { workers }\end{array}$ & $\begin{array}{l}\text { Advancing } \\
\text { workers' rights, } \\
\text { including } \\
\text { through self- } \\
\text { organization }\end{array}$ & $\begin{array}{l}\text { Limited; with } \\
\text { employers seen } \\
\text { as being } \\
\text { responsible for } \\
\text { workers' } \\
\text { problems }\end{array}$ & $\begin{array}{l}\text { Prepared to } \\
\text { lobby } \\
\text { government, } \\
\text { while sceptical } \\
\text { of its } \\
\text { effectiveness }\end{array}$ & $\begin{array}{l}\text { Strong } \\
\text { relationships }\end{array}$ & $\begin{array}{l}\text { Precarious } \\
\text { funding } \\
\text { arrangements }\end{array}$ & 'Mobilization' \\
\hline $\begin{array}{l}\text { 'Advocacy- } \\
\text { based' }\end{array}$ & $\begin{array}{l}\text { Individual } \\
\text { workers }\end{array}$ & $\begin{array}{l}\text { Advocating } \\
\text { workers' rights } \\
\text { directly, through } \\
\text { advice, support } \\
\text { and } \\
\text { representation }\end{array}$ & $\begin{array}{l}\text { Some joint } \\
\text { working (e.g. } \\
\text { training), but } \\
\text { sceptical about } \\
\text { employers' } \\
\text { behaviour }\end{array}$ & $\begin{array}{l}\text { Enforcement of } \\
\text { and compliance } \\
\text { with statutory } \\
\text { provisions }\end{array}$ & $\begin{array}{l}\text { Limited, } \\
\text { although some } \\
\text { collaborative } \\
\text { work evident }\end{array}$ & $\begin{array}{l}\text { Reliance on } \\
\text { state funding } \\
\text { (e.g. legal aid } \\
\text { budgets) }\end{array}$ & 'Public interest' \\
\hline
\end{tabular}




\begin{tabular}{|l|l|l|l|l|l|l|}
\hline $\begin{array}{l}\text { 'Service- } \\
\text { oriented' }\end{array}$ & $\begin{array}{l}\text { The state and its } \\
\text { agencies }\end{array}$ & $\begin{array}{l}\text { An emphasis on } \\
\text { delivering } \\
\text { labour market } \\
\text { services }\end{array}$ & $\begin{array}{l}\text { Based on state } \\
\text { contracts and } \\
\text { funding streams }\end{array}$ & $\begin{array}{l}\text { Balancing } \\
\text { dependency on } \\
\text { state funds with } \\
\text { challenging } \\
\text { government } \\
\text { policies }\end{array}$ & Limited & $\begin{array}{l}\text { Project and } \\
\text { contract-based } \\
\text { funding, often } \\
\text { from } \\
\text { government } \\
\text { agencies }\end{array}$ \\
\hline
\end{tabular}

